\title{
The Entrepreneur's Psychological Capital, Creative Innovation Behavior, and Enterprise Performance
}

\author{
Qianying Gao, Cisheng Wu*, Linchuan Wang and Xuyang Zhao
}

School of Management, Hefei University of Technology, Hefei, China

In order to analyze the relationship between entrepreneur psychological capital, creative innovation behavior, and enterprise performance based on the actual situation of Chinese enterprises and provide a theoretical basis for the application of entrepreneur

\section{OPEN ACCESS}

Edited by:

Yenchun Jim Wu,

National Taiwan Normal University,

Taiwan

Reviewed by:

Ivy Cao,

Dongbang Culture University,

South Korea

Alex Zhai,

Louisiana State University,

United States

*Correspondence:

Cisheng Wu

cswu@hfut.edu.cn

Specialty section:

This article was submitted to

Organizational Psychology,

a section of the journal

Frontiers in Psychology

Received: 16 March 2020

Accepted: 17 June 2020

Published: 24 July 2020

Citation:

Gao Q, Wu C, Wang L and Zhao X (2020) The Entrepreneur's

Psychological Capital, Creative Innovation Behavior, and Enterprise

Performance.

Front. Psychol. 11:1651

doi: 10.3389/fpsyg.2020.01651 psychological capital in enterprise innovation and performance development, in this study, 536 entrepreneurs from 517 enterprises in different fields in Anhui region were selected, and a questionnaire survey on the psychological capital of entrepreneurs, creative innovation behaviors, and corporate performance was conducted. A hypothesis model of the relationship between entrepreneur's psychological capital, creative innovation behavior, and enterprise performance was constructed. The correlation between entrepreneur's psychological capital, creative innovation behavior, and enterprise performance and the intermediation of creative innovation behavior were analyzed using multiple-regression model and structural equation model. The results show that there is a significant positive correlation between dimensions of self-efficacy (regression coefficient $=0.682, p=0.000$ ), toughness (regression coefficient $=0.526$, $p=0.000$ ), and enterprise performance; there is a significant positive correlation between the dimensions of optimism (regression coefficient $=0.471, p=0.003$ ), hope (regression coefficient $=0.590, p=0.006$ ), and enterprise performance; there is a significant positive correlation between entrepreneurs' technological innovation behavior (regression coefficient $=0.506, p=0.000$ ), business innovation behavior (regression coefficient $=0.562, p=0.000$ ), and enterprise performance; there is a significant positive correlation between entrepreneurial relationship acquisition behavior (regression coefficient $=0.632, p=0.004$ ) and enterprise performance. Taking entrepreneurs' creative innovation behavior as the intermediary variable, the authors conclude that the dimensions of entrepreneurs' self-efficacy, hope, optimism, toughness, and the standardized path coefficient of enterprise performance are significantly reduced; through the analysis of structural equation model, it is found that the fitting index of the model of entrepreneur's psychological capital, creative innovation behavior, and enterprise performance meets the fitting standard, which shows that both the 
psychological capital and the creative innovation behavior of entrepreneurs can promote the improvement of enterprise performance. Entrepreneur's creative innovation behavior plays an intermediary effect in the positive influence of entrepreneur's psychological capital on enterprise performance.

Keywords: entrepreneur psychological capital, creative innovation behavior, enterprise performance, structural equation model, multiple regression model

\section{INTRODUCTION}

Psychological capital is a psychological resource that can play a positive role in promoting oneself, development, and the growth of enterprise performance, and it is a positive psychological state that individuals show in their work growth (Bouzari and Karatepe, 2020; Gray et al., 2020). Psychological capital consists of four dimensions, namely, self-efficacy, hope, optimism, and toughness. In recent years, it has become the research object of many scholars in positive organizational behavior (Funken et al., 2020; Ma et al., 2020; Sadq et al., 2020). Through analysis on the online questionnaire and structural equation model completed by 215 science and engineering students in Indonesia, Mahfud et al. (2020) found that the relationship between psychological capital dimensions and entrepreneurial attitude orientation and entrepreneurial intention has a positive partial mediating effect. Kusumawardani et al. (2020) analyzed the entrepreneurial psychology of 352 female entrepreneurs in the Bali tourism industry using the theoretical framework of planned behavior and structural equation model, and found that psychological capital and entrepreneurship education indirectly affected entrepreneurial intention through the two intermediary variables of personal attitude and perceived behavior control. With the advent of the era of economic globalization, many enterprises are facing severe tests. As an important factor for the future development of companies, entrepreneurs also play a very important role in the improvement of corporate performance (Li et al., 2016; Ahmed et al., 2020). As a result, the research on the psychological capital of entrepreneurs is beneficial to the long-term development of enterprises.

Creative innovation has always been a kind of breakthrough thinking pursued by people. For enterprises, the power of creative innovation is the long-term guarantee for the improvement of enterprise performance (Rego et al., 2016, 2017). Since the end of the 20th century, China's economic and social transformation, entrepreneurship, and innovation economy have become the strategic focus of future development, and also the focus of many scholars. Domi et al. (2020) found in their survey of 211 Albanian tourism SMEs that innovation and innovation behaviors play an intermediary role in the relationship between enterprise synergy and performance. Kurniawan et al. (2020) conducted a questionnaire survey on 150 enterprise personnel in the creative industry and found that there was a significant positive correlation between knowledge sharing and absorptive ability and creative and innovative ability $(p<0.05)$. The creative industry develops better by increasing knowledge sharing, absorptive capacity, and innovation capacity. At present, the mainstream understanding of creative innovation behavior is to regard creative capital as an abstract concept of creativity, and the research mainly focuses on countries and regions and other macro levels, with little involvement in entrepreneurs and individuals (Deligianni et al., 2019; He and Hui, 2020). Therefore, the research on entrepreneurs' creative innovation behaviors is beneficial to the development of enterprises.

To sum up, the current research on the relationship between entrepreneur psychological capital, creative capital, and organizational performance is too macroscopic, and there are few reports on individual entrepreneurs. Based on this, 536 entrepreneurs from 517 enterprises in different fields in the Anhui region were taken as research objects, and a hypothesis model of the relationship between entrepreneur psychological capital, creative innovation behavior, and enterprise performance was constructed. The relationship between entrepreneur's psychological capital, creative innovation behavior, and enterprise performance was evaluated using multiple-regression model and structural equation model (Yu et al., 2019).

\section{LITERATURE REVIEW}

As the fourth largest capital in entrepreneurship, the psychological capital of entrepreneurs can directly affect every link in the process of entrepreneurship, which has attracted the attention of many scholars. Baron et al. (2016) proposed that people who were attracted, selected, but persisted in starting a business may have a high bearing capacity, and psychological capital was positively correlated with subjective well-being based on the principle of attract-select-loss. Anglin et al. (2018) expanded the entrepreneurship literature to include positive psychological capital-the level of psychological resources of a person or organization, including hope, optimism, resilience, and confidence-as a significant signal of crowdfunding. It turned out that using positive psychological capital language can improve the performance of crowdfunding. They also looked at 1726 Kickstarter campaigns and found that entrepreneurs who delivered positive psychological capital had excellent fundraising performance. Enterprises need to create benefits to distribute benefits, so enterprise performance is also the most concerned issue in the process of entrepreneurship, and the role of entrepreneurs' own psychological capital on enterprise performance has attracted the attention of many scholars. Digan et al. (2019) conducted a sample survey of 369 female entrepreneurs of small and medium-sized enterprises in Gujarat, western India, and found that female entrepreneurs can cope with the challenges of self-employment through psychological capital, so as to obtain more corporate 
benefits from empowerment. Baluku et al. (2018) studied the influence of psychological capital and autonomy on entrepreneurial performance using the self-determination theory and psychological capital literature. It was found that entrepreneurs were satisfied with the influence of psychological capital, autonomy, and their interaction with commitment and that psychological capital had significant influence on training and entrepreneurial performance. Probst et al. (2017) studied whether the "psychological capital" of high-level structural leadership composed of hope, self-efficacy, resilience, and optimism can ease the relationship between job insecurity and performance of employees. The results showed that leaders with high level of psychological capital can reduce employees' sense of insecurity and improve organizational performance. Edwards and Rowe (2019) constructed a framework for the relationship between psychological capital, employees' mental health, and corporate performance and tested the role of this structure in employees' mental health and job satisfaction. The results showed that the psychological capital of leaders can be used as a partial intermediary or a complete intermediary to increase the job satisfaction and mental health of employees, so as to improve the development of enterprise performance. To sum up, the current analysis on the effect of entrepreneur psychological capital on enterprise performance is a hot topic. An in-depth discussion on the relationship between the psychological capital of entrepreneurs, creative innovation behavior, and enterprise performance was explored to provide a theoretical basis for the practical application of psychological capital.

\section{METHODOLOGY}

\section{Research Subjects}

In this study, 536 entrepreneurs from 517 enterprises in different fields in Anhui region were selected as research objects. A total of 615 questionnaires were issued, and 579 copies were responded, with a response rate of $94.15 \%$. After careful examination and elimination of invalid data, there were 536 valid questionnaires, with a valid response rate of $87.15 \%$.

The basic characteristics of the enterprise were selected as shown in Table 1. Among the enterprises, private enterprises are the largest, accounting for $54.16 \%$. The Internet enterprises in the industry are the largest, accounting for $39.65 \%$. In terms of company compensation, the number of non-highpaying enterprises is significantly higher than that of high-paying enterprises, accounting for $53.77 \%$. In terms of the number of employees, there are more small enterprises with employees from 1 to 200 , accounting for $61.32 \%$.

The basic characteristics of entrepreneurs are shown in Table 2. In terms of age, entrepreneurs aged 3040 years are the most, accounting for $37.87 \%$; in terms of educational background, entrepreneurs with bachelor's degree have the highest level (46.64\%); in terms of gender, male entrepreneurs are significantly more than female entrepreneurs, accounting for $63.25 \%$.
TABLE 1 | Basic information of all tested enterprises.

\begin{tabular}{llcc}
\hline $\begin{array}{l}\text { Enterprises } \\
\text { variables }\end{array}$ & Classification & $\begin{array}{c}\text { Number of the } \\
\text { samples }\end{array}$ & Proportion \\
\hline Type of the & Private & 280 & $54.16 \%$ \\
enterprise & Foreign capital & 84 & $16.25 \%$ \\
& Sino-foreign joint & 59 & $11.41 \%$ \\
& Other types & 94 & $18.18 \%$ \\
Industry & Internet & 205 & $39.65 \%$ \\
& Real estate & 125 & $24.18 \%$ \\
& Services & 134 & $25.92 \%$ \\
Pay & Other industries & 53 & $10.25 \%$ \\
& High-paying & 156 & $30.17 \%$ \\
& Non-high-paying & 278 & $53.77 \%$ \\
Number of the & Not clear & 83 & $16.06 \%$ \\
employees & 1-200 & 317 & $61.32 \%$ \\
& 201-900 & 126 & $24.37 \%$ \\
& More than 900 & 74 & $14.31 \%$ \\
\hline
\end{tabular}

TABLE 2 | Basic information of selected entrepreneurs.

\begin{tabular}{llcc}
\hline Entrepreneurs & Classification & $\begin{array}{c}\text { Number of the } \\
\text { samples }\end{array}$ & Proportion \\
\hline Age & No more than 30 & 76 & $14.18 \%$ \\
& $30-40$ & 203 & $37.87 \%$ \\
Educational & Se-50 & 148 & $27.61 \%$ \\
background & More than 50 & 109 & $20.34 \%$ \\
& Junior college & 56 & $10.45 \%$ \\
Gender & Machelor degree & 126 & $23.51 \%$ \\
& Master's degree and above & 250 & $46.64 \%$ \\
& Females & 104 & $19.40 \%$ \\
& & 339 & $63.25 \%$ \\
& & 197 & $36.75 \%$ \\
\hline
\end{tabular}

\section{Research Hypotheses}

Enterprise performance is the result of the interaction and matching between the internal data distribution and the external environment, which is influenced by many factors. However, there is no uniform standard for the measurement of enterprise performance in previous studies, and it lacks of official nature. Therefore, a single enterprise performance dimension is proposed and the following hypotheses are put forward.

\section{Entrepreneur Psychological Capital and Enterprise Performance}

F1: Psychological capital of entrepreneurs has a positive effect on enterprise performance.

F11: Entrepreneurs hope that the dimension has a positive impact on enterprise performance.

F12: The dimension of entrepreneur self-efficacy has a positive influence on enterprise performance.

F13: The entrepreneurial optimism dimension has a positive impact on enterprise performance. 
F14: The dimension of entrepreneur toughness has a positive impact on enterprise performance.

\section{Entrepreneurial Creative Innovation Behavior and Organizational Learning Ability}

F2: Entrepreneurs' creative innovation behavior has a positive impact on enterprise performance.

F21: Entrepreneurs' technological innovation has a positive impact on enterprise performance.

F22: The creative innovation behavior of entrepreneurs' business model has a positive impact on enterprise performance.

F23: The acquisition of entrepreneurial relationship ability has a positive effect on enterprise performance.

\section{Entrepreneur Psychological Capital, Creative} Innovation Behavior, and Enterprise Performance

F3: Entrepreneur's creative innovation behavior plays an intermediary effect in the influence of entrepreneur's psychological capital on enterprise performance.

F31: The technological innovation of entrepreneurs plays a mediating role in the influence of entrepreneur's psychological capital on enterprise performance.
F32: The innovation behavior of entrepreneur's business model plays an intermediary effect in the influence of entrepreneur's psychological capital on enterprise performance.

F33: The behavior of acquiring entrepreneurial relationship ability plays an intermediary effect in the influence of entrepreneurial psychological capital on enterprise performance.

\section{The Hypothesis Model of the}

\section{Relationship Between Entrepreneurial}

Psychological Capital, Creative Innovation Behavior, and Enterprise Performance

In the empirical study, the relationship model of entrepreneur psychological capital, creative innovation behavior, and enterprise performance as shown in Figure $\mathbf{1}$ can be constructed based on the above hypothesis. The independent variables of this study are entrepreneur psychological capital, including self-efficacy, optimism, hope, and toughness. The intermediary variables are entrepreneur's creative innovation behavior, including entrepreneur's technological innovation behavior, entrepreneur's business model innovation behavior, and entrepreneur's relationship ability acquisition behavior. The dependent variable is enterprise performance. Based on the

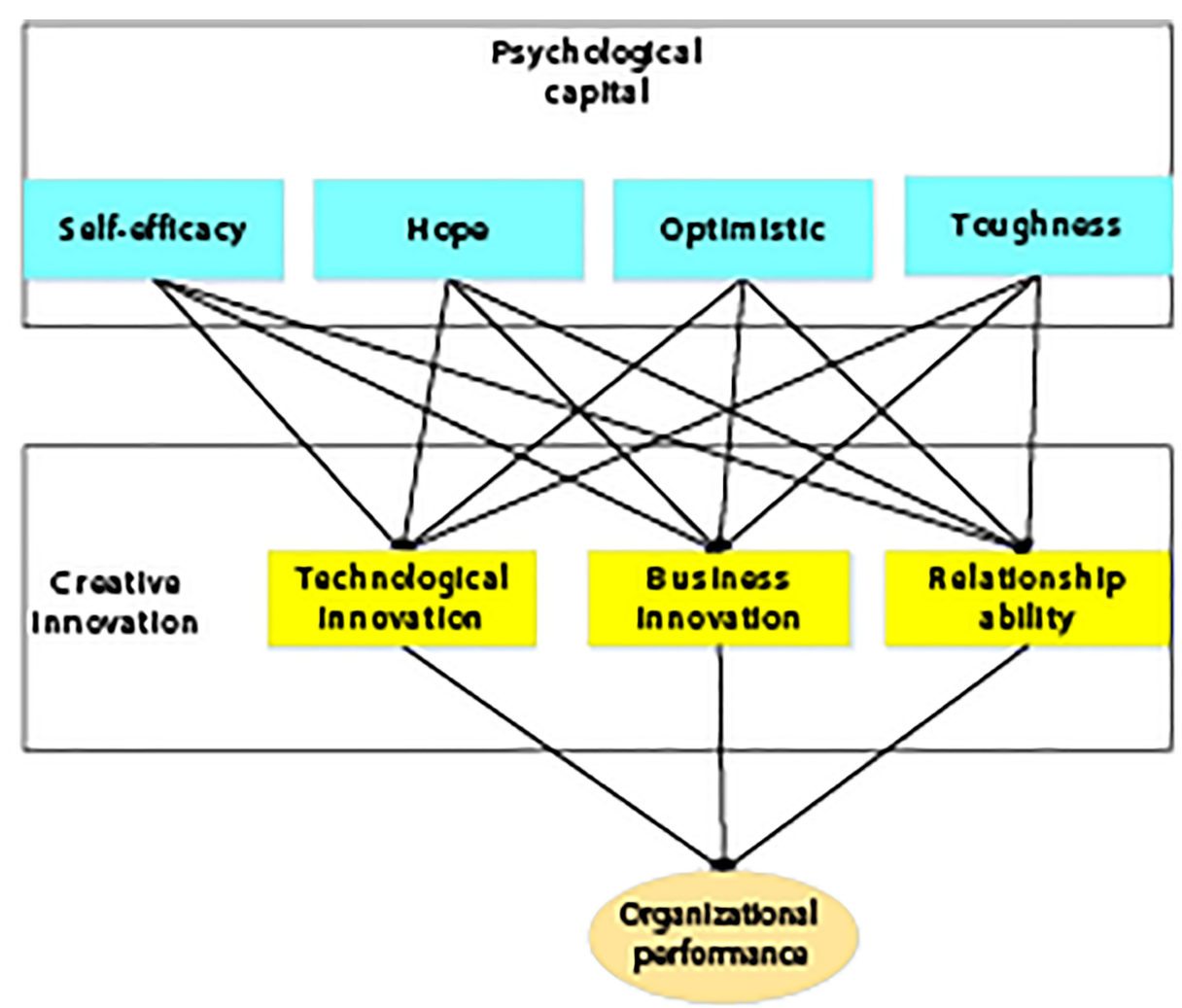

FIGURE 1 | The relationship model of entrepreneur's psychological capital, creative innovation behavior, and enterprise performance. 
current entrepreneurial environment, the psychological capital of entrepreneurs can positively affect the performance of enterprises through creative innovation behaviors.

\section{Questionnaire Design}

In empirical research, questionnaire survey is a common research method used by scholars, which can easily and quickly obtain a lot of required data and has a certain degree of reliability. Therefore, according to the theoretical hypothesis proposed in this study and the relationship model of entrepreneur's psychological capital, creative innovation behavior, and enterprise performance, the variables to be measured are identified as entrepreneur's psychological capital, enterprise performance, and entrepreneur's creative innovation behavior. The scale tools are entrepreneur psychological capital scale, enterprise performance scale, and entrepreneur creative innovation behavior scale.

\section{The Entrepreneur Psychological Capital Scale}

As shown in Table 3, the questionnaire includes four dimensions: self-efficacy, hope, optimism, and toughness. Self-efficacy consists of six measurement items. The hope dimension includes six measurement items, the optimism dimension includes six

TABLE 3 | The entrepreneur psychological capital scale.

\begin{tabular}{|c|c|}
\hline Variables & Measurement items \\
\hline \multirow{6}{*}{$\begin{array}{l}\text { Self-efficacy } \\
\text { sense }\end{array}$} & I believe I can solve complicated problems \\
\hline & I believe that I can express and do my job well \\
\hline & $\begin{array}{l}\text { I believe I can make a contribution to the future } \\
\text { development of the company }\end{array}$ \\
\hline & $\begin{array}{l}\text { I believe that I can set the future development goals for the } \\
\text { company }\end{array}$ \\
\hline & $\begin{array}{l}\text { I believe that I can communicate and coordinate the } \\
\text { relationship with the outside world }\end{array}$ \\
\hline & I believe I can deliver effective information in a timely manner \\
\hline \multirow[t]{6}{*}{$\begin{array}{l}\text { Hope } \\
\text { dimension }\end{array}$} & $\begin{array}{l}\text { I can come up with many solutions when I am faced with } \\
\text { difficulties at work }\end{array}$ \\
\hline & I can throw myself into my work \\
\hline & I believe there are many solutions to any problem \\
\hline & I think I can succeed in my job \\
\hline & I am confident of achieving and exceeding my goals \\
\hline & I am achieving the work goals I set for myself \\
\hline \multirow{6}{*}{$\begin{array}{l}\text { Optimism } \\
\text { dimension }\end{array}$} & I have a positive attitude \\
\hline & Sometimes I work hard but I still make mistakes \\
\hline & I always look on the bright side of my work \\
\hline & I am optimistic about the future development of my work \\
\hline & All the work runs counter to my ideas \\
\hline & At work, I always believe that "behind the dark is the light" \\
\hline \multirow{8}{*}{$\begin{array}{l}\text { Toughness } \\
\text { dimension }\end{array}$} & I will often become depressed and distracted \\
\hline & $\begin{array}{l}\text { In the face of work, I will try every means to solve the } \\
\text { problem }\end{array}$ \\
\hline & I believe I can do it alone \\
\hline & In my work, I go all out regardless of my emotions \\
\hline & I'm getting closer to my goal \\
\hline & I am calm under pressure \\
\hline & I'm experienced enough and believe I can handle anything \\
\hline & I'm full of energy every day \\
\hline
\end{tabular}

measurement items, and the toughness dimension includes eight measurement items. Richter's five points are used for each item: 1 for strongly disagree, 2 for disagree, 3 for neither agree nor disagree, 4 for agree, and 5 for strongly agree. The internal reliabilities of the four dimensions of self-efficacy, hope, optimism, and toughness and the overall scale are $0.81,0.79$, 0.86 , and 0.89 , respectively (Laguía et al., 2019).

\section{The Enterprise Performance Scale}

As shown in Table 4, considering that there is no unified standard for enterprise performance, the following table was developed based on previous literature, and the scale adopted seven indicators for evaluation. Richter's five points were used for each item: 1 for strongly disagree, 2 for disagree, 3 for neither agree nor disagree, 4 for agree, and 5 for strongly agree (Liu et al., 2018).

\section{Entrepreneur Creative Innovation Behavior Scale}

As shown in Table 5, the scale includes three dimensions: entrepreneur's technological innovation, entrepreneur's business innovation, and entrepreneur's relationship acquisition behavior. Entrepreneur's technological innovation behavior includes five measurement items, entrepreneur's business innovation behavior includes three measurement items, and entrepreneur's relationship acquisition behavior includes four measurement items. Richter's five points were used for each item: 1 for strongly disagree, 2 for disagree, 3 for neither agree nor disagree, 4 for agree, and 5 for strongly agree (Roopsing and Nokphromphanao, 2018). The internal consistency reliabilities of the three dimensions of entrepreneur's technological innovation, business innovation, and relationship acquisition behavior and the overall scale are $0.86,0.83$, and 0.91 , respectively.

\section{Analysis Method}

SPSS19.0 was used to process the data in this study. The counting data were expressed as a percentage (\%). The relationship between entrepreneur's psychological capital and enterprise performance, the relationship between entrepreneur's creative innovation behavior and enterprise performance, and the intermediary effect of entrepreneur's creative innovation behavior on enterprise performance were investigated using AMOS 24.0 software. Besides, Spearman correlation was used to analyze the correlation between each dimension of entrepreneur's psychological capital, creative innovation

TABLE 4 | The enterprise performance scale.

\begin{tabular}{ll}
\hline Variables & Measurement items \\
\hline Enterprise & The return on total assets is slightly higher than its peers \\
performance & The return on equity is slightly higher than that of its peers \\
& The company's total sales growth is slightly higher than that \\
of its peers & The competitiveness of the company in the same industry \\
& Number of patented products \\
& The position of new products in the industry \\
& Financial trouble not encountered ever
\end{tabular}


TABLE 5 | Entrepreneur creative innovation behavior scale.

\begin{tabular}{ll}
\hline Variables & Measurement items \\
\hline $\begin{array}{l}\text { Technological } \\
\text { innovation }\end{array}$ & The management considers the company's ability \\
of entrepreneurs & to learn to be our competitive advantage \\
& The company regards learning as one of the core \\
& values for future development and improvement \\
& The company sees learning as an investment rather \\
& than a cost \\
& The enterprise sees active learning as a necessary \\
& quality for future survival \\
& The enterprise does not attach importance to the \\
learning of employees & I focus on business model innovation \\
I encourage my employees, customers, and others & to provide ideas and suggestions for business \\
model innovation \\
business creativity and \\
innovation
\end{tabular}

behavior, and enterprise performance. Afterward, the $t$-test was used for comparison of different demographic variables in the psychological capital group. $p<0.05$ indicates that the difference is statistically significant.

\section{RESULTS}

\section{Difference Analysis of Different Demographic Variables}

As shown in Table 6, in terms of gender, the psychological capital toughness of male is significantly higher than that of female $(p<0.05)$. In terms of education background, self-efficacy of entrepreneurs with bachelor's degree, master's degree, or above is significantly higher than that of junior college, senior high school or below $(p<0.05)$. In terms of age, the optimism dimension of entrepreneurs under 30 years of age is significantly higher than that of entrepreneurs over 30 years old $(p<0.05)$. The hope dimension of psychological capital of entrepreneurs under the age of 0 is significantly higher than that over the age of 40 $(p<0.05)$.

\section{Spearman Correlation Analysis of Entrepreneur Psychological Capital, Creative Innovation Behavior, and Enterprise Performance}

Spearman correlation was first used to analyze whether there was a significant correlation between the psychological capital of entrepreneurs, creative innovation behavior, and enterprise performance. As shown in Table 7, the dimensions of entrepreneurs' self-efficacy and toughness are significantly correlated with enterprise performance $(p<0.001)$; the dimensions of entrepreneurs' hope and optimism are significantly correlated with enterprise performance $(p<0.05)$. Among them, the correlation between self-efficacy and enterprise performance is the strongest $(r=0.801)$.

As shown in Table 8, there is a very significant correlation between entrepreneurs' technological innovation behavior and business innovation behavior and enterprise performance $(p<0.001)$; there is a significant correlation between entrepreneurial relationship acquisition behavior and enterprise performance $(p<0.05)$. Among them, the correlation between technological innovation and enterprise performance is the strongest $(r=0.859)$.

TABLE 7 | Spearman correlation analysis between each dimension of entrepreneur psychological capital and enterprise performance.

\begin{tabular}{lcccc}
\hline $\begin{array}{l}\text { Entrepreneur } \\
\text { psychological capital }\end{array}$ & Self-efficacy & Hope & Optimism & Toughness \\
\hline $\begin{array}{l}\text { Entrepreneur } \\
\text { psychological capital } r\end{array}$ & 0.801 & 0.653 & 0.710 & 0.758 \\
$P$ & 0.000 & 0.006 & 0.003 & 0.000
\end{tabular}

TABLE 6 | Analysis on the difference of psychological capital of different gender, age, and educational background.

\begin{tabular}{|c|c|c|c|c|c|}
\hline Variables & & Self-efficacy & Optimism & Toughness & Hope \\
\hline \multirow[t]{2}{*}{ Gender } & Male & 24.58 & 26.75 & $34.58 \mathrm{a}$ & 25.08 \\
\hline & Female & 25.12 & 26.36 & $29.59 b$ & 25.96 \\
\hline \multirow[t]{4}{*}{ Educational background } & Senior high school and below & $23.19 a$ & 25.99 & 32.51 & 25.61 \\
\hline & Junior college & $24.07 a$ & 26.16 & 32.74 & 25.17 \\
\hline & Bachelor's degree & $26.84 b$ & 26.31 & 33.16 & 25.24 \\
\hline & Master's degree and above & $27.01 b$ & 26.07 & 32.35 & 26.02 \\
\hline \multirow[t]{4}{*}{ Age } & No more than 30 & 24.93 & $27.32 \mathrm{a}$ & 32.45 & $26.32 a$ \\
\hline & $30-40$ & 25.08 & $25.33 b$ & 31.94 & $26.17 a$ \\
\hline & $40-50$ & 25.19 & $25.91 b$ & 32.84 & $24.91 b$ \\
\hline & More than 50 & 24.60 & $25.61 b$ & 32.80 & $24.86 b$ \\
\hline
\end{tabular}

Different letters a and $b$ indicate that pairwise comparison in the group has statistical significance $(p<0.05)$. 
TABLE 8 | Spearman correlation analysis between the dimensions of entrepreneurs' creative innovation behavior and enterprise performance.

\begin{tabular}{lccc}
\hline $\begin{array}{l}\text { Entrepreneur } \\
\text { psychological capital }\end{array}$ & $\begin{array}{l}\text { Technological } \\
\text { innovation }\end{array}$ & $\begin{array}{c}\text { Business } \\
\text { creativity and } \\
\text { innovation }\end{array}$ & $\begin{array}{c}\text { Relationship } \\
\text { acquisition } \\
\text { behavior }\end{array}$ \\
\hline $\begin{array}{l}\text { Enterprise performance } \\
r\end{array}$ & 0.859 & 0.817 & 0.736 \\
$P$ & 0.000 & 0.000 & 0.004 \\
\hline
\end{tabular}

TABLE 9 | Regression analysis of entrepreneur psychological capital and enterprise performance.

\begin{tabular}{lccc}
\hline Models & $\boldsymbol{T}$-value & Regression coefficient & $\boldsymbol{p}$ \\
\hline Self-efficacy & 5.617 & 0.682 & 0.000 \\
Optimism & 4.835 & 0.471 & 0.016 \\
Toughness & 6.118 & 0.526 & 0.000 \\
Hope & 5.389 & 0.590 & 0.024 \\
Age & 1.472 & 0.217 & 0.067 \\
Educational background & 5.825 & 0.543 & 0.013 \\
Gender & 1.642 & 0.271 & 0.076 \\
\hline
\end{tabular}

\section{Empirical Research on Entrepreneur Psychological Capital and Enterprise Performance}

As shown in Table 9, every dimension of entrepreneurs' psychological capital was taken as the independent variable, and organizational performance, age (under 30 years of age, 0 ; $30-40$ years of age, $1 ; 40-50$ years of age and over 50 years of age, 2; more than 50,3), educational background (below high school education, 0 ; junior college, 1; bachelor's degree, 2; master or above, 3), and gender (male, 1, female, 0) were taken as dependent variables. The regression coefficient of selfefficacy and organizational performance is 0.682 , which has a very significant positive correlation $(p<0.001)$. Thus, the hypothesis "F12: entrepreneurs' self-efficacy dimension has a positive impact on enterprise performance" is true. The regression coefficient between optimism dimension and organizational performance is 0.475 , which has a significant positive correlation $(p<0.05)$. Thus, hypothesis F13 “entrepreneur's optimism dimension has a positive impact on enterprise performance" is true. The regression coefficient between the expected dimension and organizational performance is 0.590 , with a significant positive correlation $(p<0.05)$. Thus, the hypothesis "F11: entrepreneurs' hope dimension has a positive impact on enterprise performance" is true. The regression coefficient between toughness dimension and organizational performance is 0.526 , showing a very significant positive correlation $(p<0.001)$. Thus, hypothesis "F14: entrepreneur toughness dimension has a positive impact on enterprise performance" is true. The regression coefficient between educational background and enterprise performance is 0.543 , showing a significant positive correlation $(p<0.05)$.

The relationship between variables was handled through the analysis of entrepreneur psychology scale and structural equation model. Self-efficacy was expressed by the English abbreviation SE, hope dimension is expressed by $\mathrm{HO}$, optimism dimension was expressed by OP, toughness dimension was expressed by TO, and enterprise performance is expressed by PE.

As shown in Figure 2, self-efficacy, hope dimension, optimism dimension, and toughness dimension are external latent growth variables, and enterprise performance belongs to internal latent growth variables. In addition, there are 17 residual variables. The standardized path coefficient of selfefficacy and enterprise performance is 0.312 , the standardized path coefficient of hope dimension and enterprise performance is 0.418 , the standardized path coefficient of optimism dimension and enterprise performance is 0.361 , and the standardized path coefficient of toughness dimension and enterprise performance is 0.454 . Table $\mathbf{1 0}$ is the fitting index of the relationship model between entrepreneur psychological capital and enterprise performance. The $\mathrm{X}^{2}$ fitting priority index $\left(\mathrm{X}^{2} / \mathrm{df}\right)$, the rootmean-square error approximation (RMSEA), the goodness of fitting test (GFI), the normalized fitting index (NFI), the TuckerLewis index (TLI), the cross validity test index (ECVI), and the comparison fitting index (CFI) all meet the fitting standard, and the fitting evaluation is ideal.

\section{An Empirical Study on Entrepreneurs' Creative Innovation Behavior and Enterprise Performance}

As shown in Table 11, the multiple linear regression analysis was conducted with each dimension of entrepreneurs' creative innovation behavior as independent variable and organizational performance as dependent variable, age, educational background, and gender as the control variables. The regression coefficient between technological innovation and organizational performance is 0.506 , showing a very significant positive correlation $(p<0.001)$. Thus, the hypothesis "F21: entrepreneurs' technological innovation has a positive impact on enterprise performance" is true. The regression coefficient between business innovation and organizational performance is 0.562 , showing a very significant positive correlation $(p<0.001)$. Thus, hypothesis "F22: entrepreneurs' creative innovation behavior in business model has a positive impact on enterprise performance" is true. The regression coefficient of relationship acquisition ability and organizational performance is 0.632 , showing a significant positive correlation $(p<0.01)$. Thus, the hypothesis "F23: the acquisition of entrepreneurial relationship ability has a positive impact on enterprise performance" is established. The regression coefficient between educational background and enterprise performance is 0.496, showing a significant positive correlation $(p<0.05)$.

As shown in Figure 3, technical innovation behavior is represented by the English abbreviation TE, business innovation behavior is represented by $\mathrm{BU}$, and entrepreneurial relationship acquisition behavior is represented by RE. Technological innovation behavior, business innovation behavior, and entrepreneur relationship acquisition behavior are extrinsic latent growth variables, and enterprise performance is intrinsic latent growth variables. In addition, there are 14 residual variables. The standardized path coefficient of technological innovation and enterprise performance is 0.381 , the standardized 


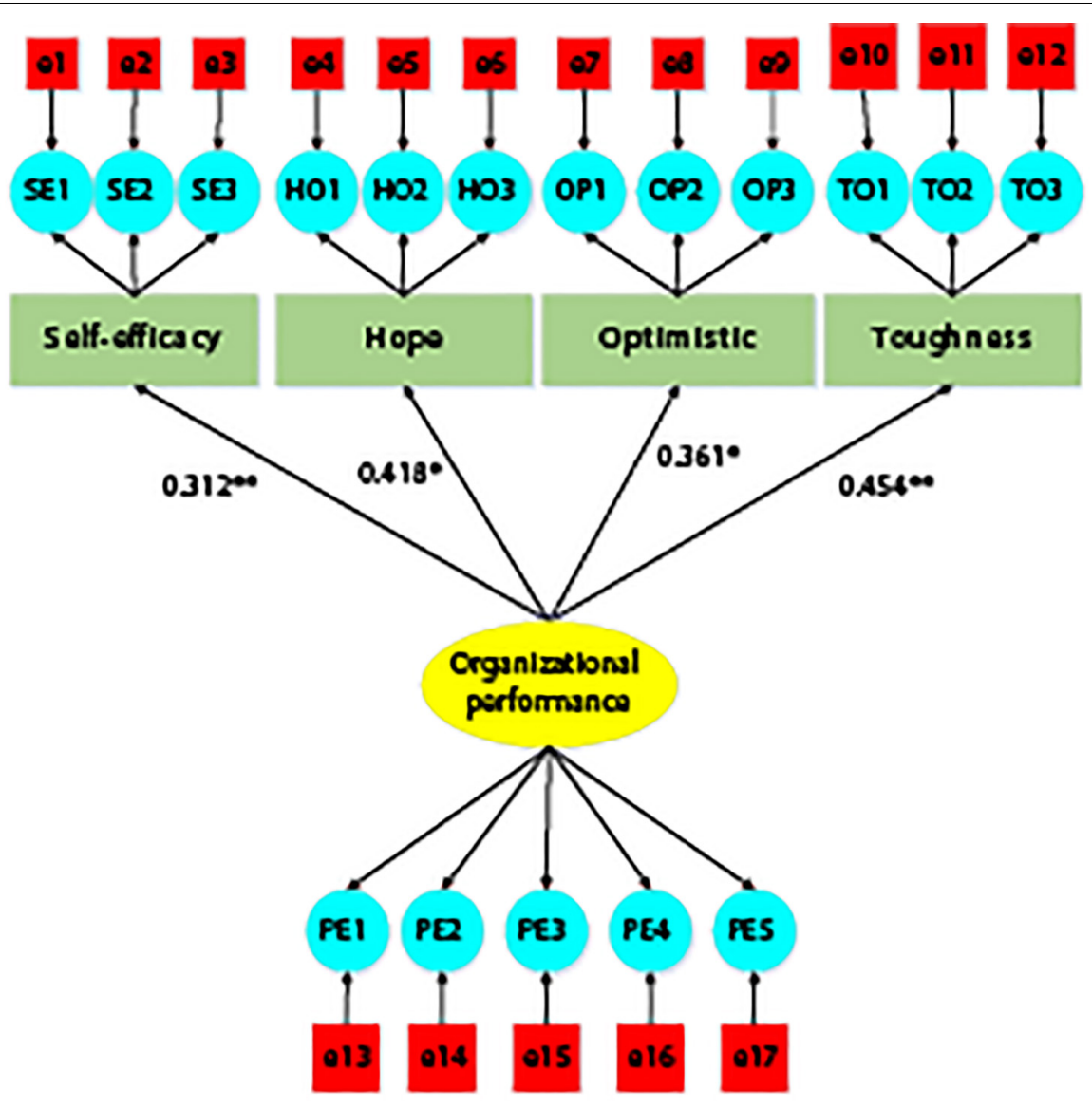

FIGURE 2 | The structural equation path analysis of the relationship model between entrepreneur psychological capital and enterprise performance. Note: * meant significant at $p<0.05$; ${ }^{*}$ meant significant at $p<0.001$.

TABLE 10 | The fitting index of the relationship model between entrepreneur psychological capital and enterprise performance.

\begin{tabular}{lccccccc}
\hline Test indicator & $\mathbf{X}^{2} / \mathbf{d f}$ & RMSEA & GFI & NFI & TLI & ECVI & CFI \\
\hline Fitting results & 2.109 & 0.052 & 1.137 & 1.295 & 1.070 & 0.683 & 1.033 \\
Fitting evaluation & Ideal & Ideal & Ideal & Ideal & Ideal & Ideal & Ideal
\end{tabular}

path coefficient of business innovation and enterprise performance is 0.353 , and the standardized path coefficient of relationship acquisition ability and enterprise performance is 0.461 . Table 12 shows the fitting index of the relationship model between entrepreneurs' creativity and innovation and enterprise performance. The $\mathrm{X}^{2} / \mathrm{df}$, RMSEA, GFI, NFI, TLI, ECVI, and CFI all meet the fitting standard, and the fitting evaluation is ideal.

\section{Empirical Research on Entrepreneur's Psychological Capital, Creative Innovation Behavior, and Enterprise} Performance

As shown in Figure 4, the entrepreneur's creative innovation behavior was taken as the intermediary variable of
TABLE 11 | Regression analysis of entrepreneurs' creative innovation behavior and enterprise performance.

\begin{tabular}{lccc}
\hline Models & $\boldsymbol{T}$-value & Regression coefficient & $\boldsymbol{p}$ \\
\hline Technological innovation & 4.591 & 0.506 & 0.000 \\
Business creativity and innovation & 5.380 & 0.562 & 0.016 \\
Relationship acquisition & 5.628 & 0.632 & 0.008 \\
Age & 3.752 & 0.362 & 0.051 \\
Educational background & 5.796 & 0.496 & 0.011 \\
Gender & 2.371 & 0.301 & 0.072 \\
\hline
\end{tabular}

the entrepreneur's psychological capital and enterprise performance, and the structural equation modeling method is applied to analyze its mechanism of action. After the inclusion of intermediary variable entrepreneurs' creative innovation behavior, the standardized path coefficient has a significant change.

After incorporating entrepreneurial technological innovation, entrepreneurial business innovation, and entrepreneurial relationship to obtain behavioral variables, the standardized path coefficient of entrepreneur self-efficacy and enterprise performance is significantly reduced from 0.312 to 0.176 ; the 


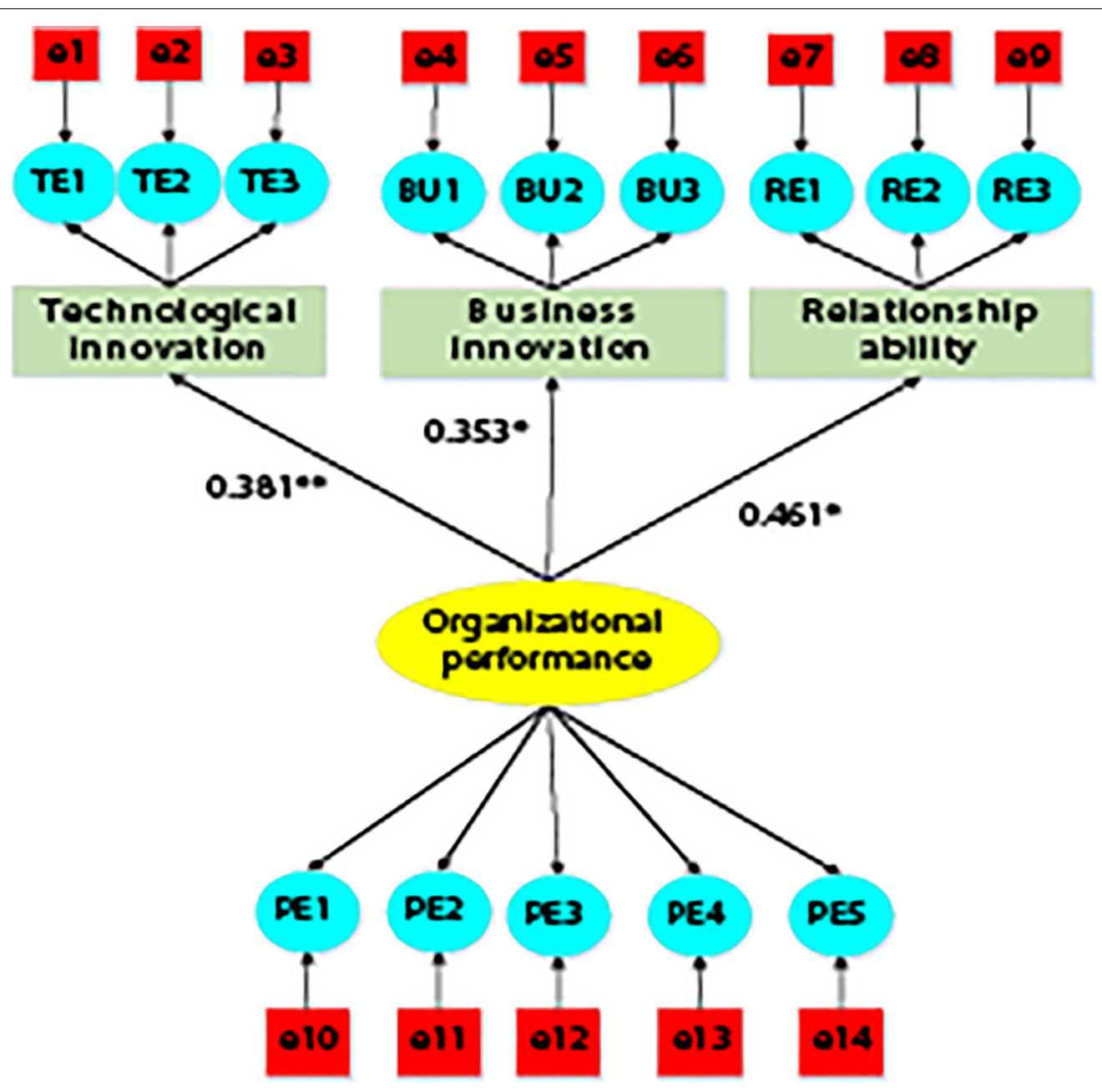

FIGURE 3 | The structural equation path analysis of the relationship model between entrepreneur's creative innovation behavior and enterprise performance. Note: * meant significant at $p<0.05$; ${ }^{\star \star}$ meant significant at $p<0.001$.

TABLE 12 | The fitting index of the relationship model between entrepreneur's creative innovation behavior and enterprise performance.

\begin{tabular}{lccccccc}
\hline Test indicator & $\mathbf{X}^{2} / \mathbf{d f}$ & RMSEA & GFI & NFI & TLI & ECVI & CFI \\
\hline Fitting results & 1.973 & 0.059 & 1.206 & 1.347 & 1.255 & 0.551 & 1.170 \\
Fitting evaluation & Ideal & Ideal & Ideal & Ideal & Ideal & Ideal & Ideal
\end{tabular}

standardized path coefficient of the dimension of entrepreneurs' hope and enterprise performance decreases significantly from 0.418 to 0.262 , the standardized path coefficient of the dimension of entrepreneurs' optimism and enterprise performance decreases significantly from 0.361 to 0.211 , and the standardized path coefficient of the dimension of entrepreneurs' toughness and enterprise performance decreases significantly from 0.454 to 0.274 ; the standardized path coefficient of entrepreneurs' technological innovation and enterprise performance is 0.335 ; and the standardized path coefficient of entrepreneurs' business innovation and enterprise performance is 0.401 . The standardized path coefficient of entrepreneurial relationship acquisition behavior and enterprise performance is 0.382 . Thus, the hypothesis "F3: entrepreneur's creative innovation behavior is the intermediary variable of entrepreneur's psychological capital affecting enterprise performance, and entrepreneur's psychological capital influences enterprise performance through entrepreneur's creative innovation behavior" is true.

\section{DISCUSSION}

Entrepreneurs are the beneficial implementers of entrepreneurial plans and activities, which determine the success of entrepreneurship. How to develop the psychological capital of entrepreneurs in the current competitive social background is an urgent problem to be solved. Therefore, the questionnaire survey method was combined with structural equation model analysis method to study 517 enterprises in different fields in Anhui region. First, it is found that the dimension of psychological capital toughness of males is significantly higher than that of females $(p<0.05)$, which is the same as the 


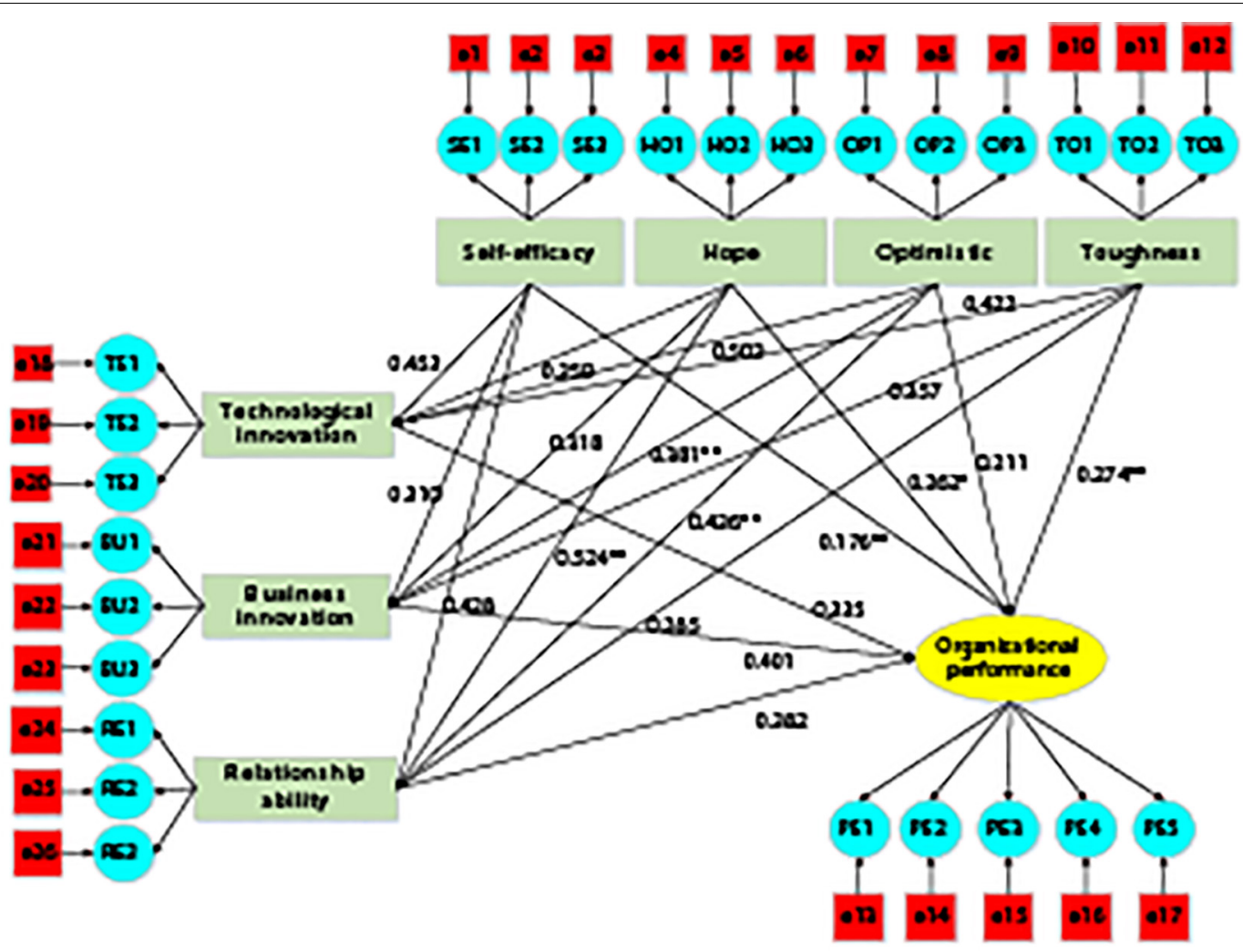

FIGURE 4 | The relationship between entrepreneurial psychological capital, creative innovation behavior, and enterprise performance path. Note: * ${ }^{2}$ eant significant at $p<0.05 ;{ }^{* \star}$ meant significant at $p<0.001$.

research results of Digan et al. (2019), suggesting that male entrepreneurs are better able to cope with stress and difficulties. The self-efficacy of entrepreneurs with bachelor's degree, master's degree, or above is significantly higher than that of junior college, senior high school, or below $(p<0.05)$, which is similar to the research results of Anokye and Asumeng (2019), suggesting that highly educated entrepreneurs have a higher degree of confidence in achieving their goals. The optimism dimension of entrepreneurs under 30 years of age is significantly higher than that of entrepreneurs over 30 years of age, and the hope dimension of entrepreneurs under 40 years of age is significantly higher than that of entrepreneurs over 40 years of age $(p<0.05)$. This may be because entrepreneurs under the age of 30 are more unmarried, have fewer worries about starting a business, and are more optimistic, while entrepreneurs under the age of 40 are regarded as the golden age of entrepreneurs, full of hope for the future (Nordin et al., 2019). The dimensions of selfefficacy and toughness are significantly positively correlated with organizational performance $(p<0.001)$, while the dimensions of optimism and hope are significantly positively correlated with organizational performance $(p<0.05)$. This is consistent with the research results of Wang et al. (2018), suggesting that all dimensions of entrepreneur psychological capital can promote the improvement of enterprise performance, but the dimensions of self-efficacy and toughness have higher positive influence than the dimensions of hope and optimism. This may be because the dimension of optimism and hope is the self-confident expression of entrepreneurs themselves, which can promote entrepreneurs to carry out innovative activities but cannot guarantee the quality of activities (Lucky, 2018). According to the analysis of the structural equation model, it is found that the fitting indexes of the relationship model between the entrepreneur's psychological capital and enterprise performance all meet the fitting criteria, which indicates that the model is supported. Thus, the hypothesis "F1: entrepreneur psychological capital has a positive impact on enterprise performance" is true.

In order to maintain the competitive advantage of enterprises in the same industry, entrepreneurs need to take risks, actively launch new products and services, and explore new markets, which requires entrepreneurs to have efficient creative innovation behaviors (Asad et al., 2018; Qian et al., 2018). In this study, it is found that entrepreneurs' technological creative innovation behavior, business creative innovation behavior, and organizational performance have extremely significant positive correlation $(p<0.001)$, while the standardized regression coefficient of entrepreneurial relationship acquisition behavior and organizational performance is 0.632 , showing a significant positive correlation $(p<0.05)$. This is consistent with the research results of Subramanian et al. (2019), which shows that each dimension of entrepreneur's creative innovation behavior has a positive promoting effect on enterprise performance, but entrepreneur's technological creative innovation behavior and 
business creative innovation behavior have higher influence than entrepreneur's relationship acquisition behavior. This may be because although entrepreneurs can make use of divergent thinking to obtain a broader knowledge space in relation degree and complete the integration of various resources, they cannot directly promote innovation activities (Obschonka et al., 2018). In addition, the structural equation model analysis found that the fitting index of the model of the relationship between entrepreneurs' creative innovation behavior and enterprise performance met the adaptation criteria, indicating that the model was supported. Thus, the hypothesis "F2: entrepreneurs' creative innovation behavior has a positive impact on enterprise performance" is true.

In addition, after the entrepreneur's creative innovation behavior was regarded as the intermediary variable of the entrepreneur's psychological capital and enterprise performance, and the structural equation model was used to analyze and find that after the entrepreneur's creative innovation behavior variable was included, the dimensions of entrepreneurs' self-efficacy, hope, optimism, and toughness and the standardized path coefficient of enterprise performance were significantly reduced. This is basically consistent with the research results of Shin et al. (2018), suggesting that the psychological capital of entrepreneurs can exert a positive effect on the performance of enterprises through the intermediary of entrepreneurs' creative innovation behaviors (Chen, 2019; Gonçalves de Lima et al., 2020). This is because the psychological capital of entrepreneurs can stimulate the divergent thinking of entrepreneurs, enhance the ability of technological and business creativity and innovation, explore new profit models, and finally continuously improve the level of enterprise performance (Pierre Johnson et al., 2019; Yan et al., 2019).

\section{CONCLUSION}

By establishing the relationship model of entrepreneur's psychological capital, creative innovation behavior, and enterprise performance path, the authors analyzed the influence of various dimensions of entrepreneur's psychological capital, creative innovation behavior on enterprise performance, and

\section{REFERENCES}

Ahmed, T., Chandran, V. G. R., Klobas, J. E., Liñán, F., and Kokkalis, P. (2020). Entrepreneurship education programmes: how learning, inspiration and resources affect intentions for new venture creation in a developing economy. Int. J. Manag. Educ. 18:100327. doi: 10.1016/j.ijme.2019. 100327

Anglin, A. H., Short, J. C., Drover, W., Stevenson, R. M., McKenny, A. F., and Allison, T. H. (2018). The power of positivity? The influence of positive psychological capital language on crowdfunding performance. J. Bus. Ventur. 33, 470-492. doi: 10.1016/j.jbusvent.2018.03.003

Anokye, E. N., and Asumeng, M. (2019). Psychological capital and achievement motivation as predictors of work engagement: a study of micro and small-scale entrepreneurs in Accra, Ghana. IFE Psychol. Intern. J. 27, 62-73.

Asad, M., Shabbir, M., Salman, R., Haider, S., and Ahmad, I. (2018). Do entrepreneurial orientation and size of enterprise influence the performance of the mediation of entrepreneur's creative innovation behavior on enterprise performance, providing a theoretical basis for the improvement of enterprise performance in the future (Shen et al., 2019). However, due to the limitations of time and economic capacity, there is no clear standard for the measurement dimension of enterprise performance. The innovative performance was used to represent enterprise performance, which had certain ambiguity. Subsequently, the enterprise performance can be divided into dimensions to make the evaluation more accurate. In a word, both entrepreneurial psychological capital and creative innovation can promote the improvement of enterprise performance (Zheng and Liu, 2020). The psychological capital of entrepreneurs can exert a positive effect on the performance of enterprises through the intermediary of entrepreneurs' creative innovation behaviors.

\section{DATA AVAILABILITY STATEMENT}

All datasets generated for this study are included in the article/supplementary material.

\section{ETHICS STATEMENT}

The studies involving human participants were reviewed and approved by the Hefei University of Technology Ethics Committee. The patients/participants provided their written informed consent to participate in this study.

\section{AUTHOR CONTRIBUTIONS}

QG: writing-original draft preparation. CW: writing-review and editing. LW: methodology. XZ: validation. All authors contributed to the article and approved the submitted version.

\section{FUNDING}

This research was supported by the China National Social Science Fund (CNSSF) (Grant No. 13AJY004).

micro and small enterprises? A study on mediating role of innovation. Manag. Sci. Lett. 8, 1015-1026. doi: 10.5267/j.msl.2018.7.008

Baluku, M. M., Kikooma, J. F., and Otto, K. (2018). Positive mindset and entrepreneurial outcomes: the magical contributions of psychological resources and autonomy. J. Small Bus. Entrepreneur. 30, 473-498. doi: 10.1080/08276331. 2018.1459017

Baron, R. A., Franklin, R. J., and Hmieleski, K. M. (2016). Why entrepreneurs often experience low, not high, levels of stress: the joint effects of selection and psychological capital. J. Manag. 42, 742-768. doi: 10.1177/0149206313495411

Bouzari, M., and Karatepe, O. M. (2020). Does optimism mediate the influence of work-life balance on hotel salespeople's life satisfaction and creative performance? J. Hum. Resour. Hosp. Tour. 19, 82-101. doi: 10.1080/15332845. 2020.1672250

Chen, M. (2019). The Impact of expatriates' cross-cultural adjustment on work stress and job involvement in the high-tech industry. Front. Psychol. 10:2228. doi: $10.3389 /$ fpsyg.2019.02228 
Deligianni, I., Voudouris, I., Spanos, Y., and Lioukas, S. (2019). Non-linear effects of technological competence on product innovation in new technologybased firms: resource orchestration and the role of the entrepreneur's political competence and prior start-up experience. Technovation 88:102076. doi: 10. 1016/j.technovation.2019.05.002

Digan, S. P., Sahi, G. K., Mantok, S., and Patel, P. C. (2019). Women's perceived empowerment in entrepreneurial efforts: the role of bricolage and psychological capital. J. Small Bus. Manag. 57, 206-229. doi: 10.1111/jsbm.12402

Domi, S., Capelleras, J. L., and Musabelliu, B. (2020). Customer orientation and SME performance in albania: a case study of the mediating role of innovativeness and innovation behavior. J. Vacat. Mark. 26, 130-146. doi: $10.1177 / 1356766719867374$

Edwards, M. B., and Rowe, K. (2019). Managing sport for health: an introduction to the special issue. Sport Manage. Rev. 22, 1-4. doi: 10.1016/j.smr.2018.12.006

Funken, R., Gielnik, M. M., and Foo, M. D. (2020). How can problems be turned into something good? The role of entrepreneurial learning and error mastery orientation. Entrepreneur. Theor. Pract. 44, 315-338. doi: 10.1177/ 1042258718801600

Gonçalves de Lima, L., Jorge Nassif, V. M., and Maria Garçon, M. (2020). The power of psychological capital: the strength of beliefs in entrepreneurial behavior. RAC Rev. Admin. Contemp. 24, 317-334.

Gray, S. M., Knight, A. P., and Baer, M. (2020). On the emergence of collective psychological ownership in new creative teams. Organ. Sci. 31, 141-164. doi: $10.1287 /$ orsc. 2019.1307

He, Q., and Hui, D. (2020). Organizational intrapreneurship policy, entrepreneur subjectivity, and employees' intrapreneurship activity. Intern. J. Inform. Syst. Serv. Sect. 12, 1-15. doi: 10.4018/ijisss.2020010101

Kurniawan, P., Hartati, W., Qodriah, S., and Badawi, B. (2020). From knowledge sharing to quality performance: The role of absorptive capacity, ambidexterity and innovation capability in creative industry. Manag. Sci. Lett. 10, 433-442. doi: $10.5267 /$ j.msl.2019.8.027

Kusumawardani, K. A., Widyanto, H. A., and Deva, I. P. L. I. (2020). Understanding the entrepreneurial intention of female entrepreneurs in the balinese tourism industry. Intern. J. Res. Bus. Soc. Sci. 9, 63-79. doi: 10.20525/ ijrbs.v9i1.611

Laguía, A., García-Ael, C., Wach, D., and Moriano, J. A. (2019). Think entrepreneur-think male: a task and relationship scale to measure gender stereotypes in entrepreneurship. Int. Entrepreneur. Manag. J. 15, 749-772. doi: 10.1007/s11365-018-0553-0

Li, Y., Wang, Z., Yang, L. Q., and Liu, S. (2016). The crossover of psychological distress from leaders to subordinates in teams: The role of abusive supervision, psychological capital, and team performance. J. Occup. Health Psychol. 21:142. doi: 10.1037/a0039960

Liu, Y. J., Gao, W., and Li, C. H. (2018). Market structure, efficiency and enterprise performance: an empirical research on wind power industry in China. Industr. Econ. Rev. 9, 37-48.

Lucky, E. O. I. (2018). An empirical examination of the influence of corporate social responsibility dimensions on the small and medium enterprise performance in Northern Malaysia. Int. J. Bus. Innov. Res. 16, 243-265.

Ma, C., Yang, J., Chen, L., You, X., Zhang, W., and Chen, Y. (2020). Entrepreneurs' social networks and opportunity identification: entrepreneurial passion and entrepreneurial alertness as moderators. Soc. Behav. Pers. 48, 1-12. doi: 10. 2224/sbp.8659

Mahfud, T., Triyono, M. B., Sudira, P., and Mulyani, Y. (2020). The influence of social capital and entrepreneurial attitude orientation on entrepreneurial intentions: the mediating role of psychological capital. Eur. Res. Manag. Bus. Econ. 26, 33-39. doi: 10.1016/j.iedeen.2019.12.005

Nordin, N., Siti-Nabiha, A. K., and Kamalia, Z. (2019). Microfinancing influence on micro-entrepreneurs business growth: mediating role of psychological and social capital. J. Entrepreneurs. Bus. Econ. 7, 130-161.

Obschonka, M., Moeller, J., and Goethner, M. (2018). Entrepreneurial passion and personality: the case of academic entrepreneurship. Front. Psychol. 9:2697. doi: 10.3389/fpsyg.2018.02697
Pierre Johnson, M., McHattie, L. S., and Champion, K. (2019). Design innovation for creative growth: modelling relational exchange to support and evaluate creative enterprise in the scottish Highlands and Islands. Artif. J. Design Pract. $6,10-11$.

Probst, T. M., Gailey, N. J., Jiang, L., and Bohle, S. L. (2017). Psychological capital: buffering the longitudinal curvilinear effects of job insecurity on performance. Saf. Sci. 100, 74-82. doi: 10.1016/j.ssci.2017.02.002

Qian, J., Song, B., Jin, Z., Wang, B., and Chen, H. (2018). Linking empowering leadership to task performance, taking charge, and voice: the mediating role of feedback-seeking. Front. Psychol. 9:2025. doi: 10.3389/fpsyg.2018. 02025

Rego, A., Owens, B., Leal, S., Melo, A., Cunha, M. P., Gonçalves, L., et al. (2017). How leader humility helps teams to be humbler, psychologically stronger, and more effective: a moderated mediation model. Leadersh. Q. 28, 639-658. doi: 10.1016/j.leaqua.2017.02.002

Rego, P., Lopes, M. P., and Nascimento, J. L. (2016). Authentic leadership and organizational commitment: the mediating role of positive psychological capital. J. Ind. Eng. Manag. 9, 129-151.

Roopsing, T., and Nokphromphanao, N. (2018). Factors Affecting Creative Innovation for Entrepreneur in the Furniture Industry Business in Asia. Asian J. Mark. 12, 12-20. doi: 10.3923/ajm.2018.12.20

Sadq, Z. M., Ahmad, B. S., Saeed, V. S., Othman, B., and Mohammed, H. O. (2020). The relationship between intellectual capital and organizational trust and its impact on achieving the requirements of entrepreneurship strategy (The case of Korek Telecom Company, Iraq). Int. J. Adv. Sci. Technol. 29, 2639-2653.

Shen, C.-W., Min, C., and Wang, C.-C. (2019). Analyzing the trend of O2O commerce by bilingual text mining on social media. Comput. Hum. Behav. 101, 474-483. doi: 10.1016/j.chb.2018.09.031

Shin, J. H., Cho, K. T., and Park, S. H. (2018). The effect of creativity of executives on innovative performance of firms: focusing on the mediating effects of entrepreneurial orientation and technological innovation orientation of research organization. Asia Pac. J. Bus. Vent. Entrepreneur. 13, 73-87. doi: 10.16972/apjbve.13.1.201802.73

Subramanian, N., Gunasekaran, A., Wu, L., and Shen, T. (2019). Role of traditional Chinese philosophies and new product development under circular economy in private manufacturing enterprise performance. Int. J. Prod. Res. 57, 7219-7234. doi: 10.1080/00207543.2018.1530467

Wang, Y., Zheng, Y., and Zhu, Y. (2018). How transformational leadership influences employee voice behavior: the roles of psychological capital and organizational identification. Soc. Behav. Pers. 46, 313-321. doi: 10.2224/sbp. 6619

Yan, X., Chen, M., and Chen, M.-Y. (2019). Coupling and coordination development of australian energy, economy, and ecological environment systems from 2007 to 2016. Sustainability 11:6568. doi: 10.3390/su11236568

Yu, C., Zhang, Z., Lin, C., and Wu, Y. (2019). Can data-driven precision marketing promote user AD clicks? Evidence from advertising in WeChat moments. Ind. Mark. Manag. 88, 414-425. doi: 10.1016/j.indmarman.2019.05.001

Zheng, Y., and Liu, S. (2020). Bibliometric analysis for talent identification by the subject-author-citation three-dimensional evaluation model in the discipline of physical education. Libr. Hi Tech. doi: 10.1108/LHT-12-2019-0248 [Epub ahead of print].

Conflict of Interest: The authors declare that the research was conducted in the absence of any commercial or financial relationships that could be construed as a potential conflict of interest.

Copyright (c) $2020 \mathrm{Gao}, \mathrm{Wu}$, Wang and Zhao. This is an open-access article distributed under the terms of the Creative Commons Attribution License (CC BY). The use, distribution or reproduction in other forums is permitted, provided the original author(s) and the copyright owner(s) are credited and that the original publication in this journal is cited, in accordance with accepted academic practice. No use, distribution or reproduction is permitted which does not comply with these terms. 